Descriptions of five morphologically and genetically confirmed new species of the Coleophora poecilella Walsingham, 1907 species group (Lepidoptera, Coleophoridae) from the Palearctic Region

\title{
Tabell, Jukka
}

2018-06-06

Tabell , J , Mutanen , M \& Sihvonen , P 2018 , ' Descriptions of five morphologically and genetically confirmed new species of the Coleophora poecilella Walsingham, 1907 species group (Lepidoptera, Coleophoridae) from the Palearctic Region ' , Zootaxa, vol. 4429 , no. 2 , pp. 331-347 . https://doi.org/10.11646/zootaxa.4429.2.8

http://hdl.handle.net/10138/236671

https://doi.org/10.11646/zootaxa.4429.2.8

cc_by

publishedVersion

Downloaded from Helda, University of Helsinki institutional repository.

This is an electronic reprint of the original article.

This reprint may differ from the original in pagination and typographic detail.

Please cite the original version. 
https://doi.org/10.11646/zootaxa.4429.2.8

http://zoobank.org/urn:Isid:zoobank.org:pub:7AC25C78-BED6-471A-BEFF-88C657667540

\title{
Descriptions of five morphologically and genetically confirmed new species of the Coleophora poecilella Walsingham, 1907 species group (Lepidoptera, Coleophoridae) from the Palearctic Region
}

\author{
JUKKA TABELL ${ }^{1}$, MARKO MUTANEN $^{2} \&$ PASI SIHVONEN ${ }^{3}$ \\ ${ }^{1}$ Laaksotie 28, FI-19600 Hartola, Finland.E-mail: jukka.tabell@phnet.fi \\ ${ }^{2}$ Department of Ecology and Genetics, P.O. Box 3000, FI-90014 University of Oulu, Finland. E-mail: marko.mutanen@oulu.fi \\ ${ }^{3}$ Finnish Museum of Natural History, Zoology Unit, University of Helsinki, P.O. Box 17, FI-00014, Finland. \\ E-mail:pasi.sihvonen@helsinki.fi
}

\begin{abstract}
Five new Coleophora species belonging to the $C$. poecilella species group are described: $C$. mirleftensis Tabell, sp. nov. from Morocco, C. embaensis Tabell, sp. nov. and C. charynensis Tabell, sp. nov. from Kazakhstan, C. nupponeni Tabell, sp. nov. from Kazakhstan and Tajikistan, and C. tugaicola Tabell, sp. nov. from Tajikistan. The male genitalia of $C$. hypomona (Falkovitsh, 1979) and the female genitalia of $C$. trichopterella Baldizzone, 1985 are illustrated for the first time. DNA barcodes are provided for each species, with a comparison to the genetically most similar species.
\end{abstract}

Key words: Gelechioidea, DNA barcoding, new taxon, male genitalia, female genitalia, biology

\section{Introduction}

In the unfinished revision of Palearctic Coleophoridae by S. Toll (1962) the genus Coleophora was divided into 37 species groups. In this system the $8^{\text {th }}$ group, $1^{\text {st }}$ section comprised six taxa, namely Coleophora poecilella Walsingham, 1907, C. traganella Chrétien, 1915, C. aglabitella Chrétien, 1915, C. klimeschiella Toll, 1952, C. gracilella Toll, 1952 and $C$. ochroflava Toll, 1961. Subsequently, several additional new species belonging to the C. poecilella species group have been described from the western and central parts of the Palearctic region (e.g. Baldizzone 1985; Glaser 1981; Falkovitsh 1972, 1982).

The adults of the $C$. poecilella species group are off-white to grey with darker irroration, or yellowish to reddish brown with an off-white costal line. The abdominal tergal sclerites are long and narrow. The resting position of several species is unique among Coleophoridae: unlike in the majority of species, the antennae are not pointed forward, but folded backwards along the forewings (e.g. in C. klimeschiella, C. pseudopoecilella Klimesch, 1982, C. macilenta Falkovitsh, 1972 and C. mirleftensis Tabell, sp. nov.; own observations). However, in some species the antennae are erected, e.g. in C. trichopterella and C. feoleuca Baldizzone, 1989 (own observations). The male genitalia are simple, the apex of the sacculus being pointed, cucullus moderately broad, and the outer margin of the valvula angled. In the female genitalia, the sterigma is divided and the ductus bursae is membranous, usually with a narrow sclerotized medial band.

\section{Material and methods}

The present article is based on the study of rich material derived from collecting trips to Kazakhstan carried out by Kari Nupponen, and to Tajikistan by Timo Nupponen and Risto Haverinen, supplemented by material collected by the first author from Spain and Morocco. All holotypes are deposited in the collections of MZH (Helsinki, Finland) or NUPP (Espoo, Finland, material available for loan via MZH); a few paratypes also in the collection of TAB (Hartola, Finland). 
The photos of adult specimens were taken with Canon EOS 7D, MP-E $65 \mathrm{~mm} \mathrm{f} / 2.8$ Macro \& EF $100 \mathrm{~mm} \mathrm{f} / 2.8$ L IS USM Macro. Focus stacking was done with Cognisys StackShot and Helicon Focus 6.7.1 and final image editing with Adobe Photoshop CS5.1. The genitalia preparations were made following standard techniques (Robinson 1976), but the genitalia were not stained. The genitalia were photographed in ventral view with a Leica DM1000 microscope and integrated Leica DF295 digital camera. Some taxa were photographed in 2-6 images of different depth of focus and combined into single images using image-stacking software as implemented in Photoshop CS6.0. The final plates were compiled with CorelDraw 2017.

A part of the collected material was sequenced for the standard DNA barcode region (Hebert et al. 2003) for preliminary detection of genetically distinct taxa and obtaining molecular data for new species. The K2P divergences between the taxa described herein and 14 more species of the C. poecilella species group were calculated using the barcode gap analysis tool of BOLD systems v. 4.0 (http://www.boldsystems.org), and are presented in Table 1. A neighbor-joining tree (Fig. 9) was constructed using MEGA 7.0 (Kumar et al. 2016). Details of successfully sequenced voucher specimens, including voucher data, images and GenBank accession numbers, are publicly available through the dataset DS-COLPOE at www.boldsystems.org and at doi: dx.doi.org/ 10.5883/DS-COLPOE.

Abbreviations:

MZH = Finnish Museum of Natural History, University of Helsinki, Finland

NUPP $=$ research collection of T. \& K. Nupponen, Espoo, Finland

$\mathrm{TAB}=$ research collection of J. Tabell, Hartola, Finland

Coleophora mirleftensis Tabell, sp. nov.

Barcode Index Number: BOLD:ACT4659

Figs. 1, 7, 9, 10-13, Table 1

Type material. Holotype $\widehat{\delta}$ : Morocco, Mirleft 5 km SSW, N29.53821 W10.05780, 20 m, 28.IV.2013, J. Tabell

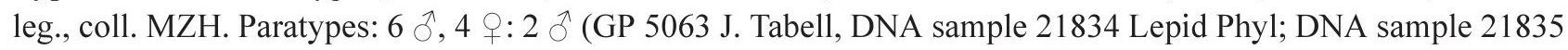
Lepid Phyl) same collecting data as in holotype; $4 \hat{\jmath}, 4$ ㅇ (GP 5467 J. Tabell, DNA sample 24598 Lepid Phyl) Morocco, Mirleft 5 km SW, N29.541 W10.065, 5 m, e[x].1[arva]. 2015, Salsola sp. 12.IV.2015, J. Tabell leg. Paratypes in coll. TAB.

Diagnosis. Based on similarities in male genitalia C. mirleftensis sp. nov. is close to C. trichopterella Baldizzone, 1985 and C. charynensis Tabell, sp. nov. Diagnostic features are the apex of sacculus with only one protuberance in C. mirleftensis (two protuberances in C. trichopterella and C. charynensis), the outer margin of valvula (rounded in C. mirleftensis, triangular in C. trichopterella, largely folded in C. charynensis) and the length of cornuti (shortest in C. mirleftensis, longest in C. trichopterella). In the female genitalia of $C$. mirleftensis, the long median lamina in the ductus bursae is characteristic.

Molecular diagnosis. Three specimens of C. mirleftensis were sequenced, resulting in $657 \mathrm{bp}, 608 \mathrm{bp}$, and 604 bp DNA barcode fragments. The barcodes were compared to those of C. charynensis $(\mathrm{n}=2)$ and C. trichopterella $(\mathrm{n}=1)$, as well as to those of 16 additional taxa of the $C$. poecilella species group. The resultant sequences revealed 7.05-11.91\% divergences among barcoded species (Table 1). The divergence between $C$. mirleftensis and $C$. charynensis $(\mathrm{n}=2)$ and $C$. trichopterella $(\mathrm{n}=1)$ was $7.05 \%$ and $8.26 \%$, respectively (Table 1$)$. The barcodes of $C$. mirleftensis display no intraspecific variation, the seeming variation in the neighbor-joining tree (Fig. 9) resulting from the different lengths of the sequences alone.

Description. Wingspan 12-13 mm. Head dark fuscous. Antenna long, light fuscous. Scape dark fuscous. Labial palpus ascending, pale brown mixed with white, not tufted, third segment darker, second segment $1.5 \mathrm{x}$ longer than third segment. Thorax and tegula fuscous. Forewing creamy white, almost entirely covered with fuscous scales, irrorated with dark brown scales, near the base a large dark brown subcostal fleck; off-white colour visible along costa and dorsum. Costal fringe dark fuscous, dorsal fringe paler. Hindwing pale grey, fringe pale fuscous. Hindtibia thickened by hair-like pale fuscous scales. Abdomen fuscous, slightly lustrous. 

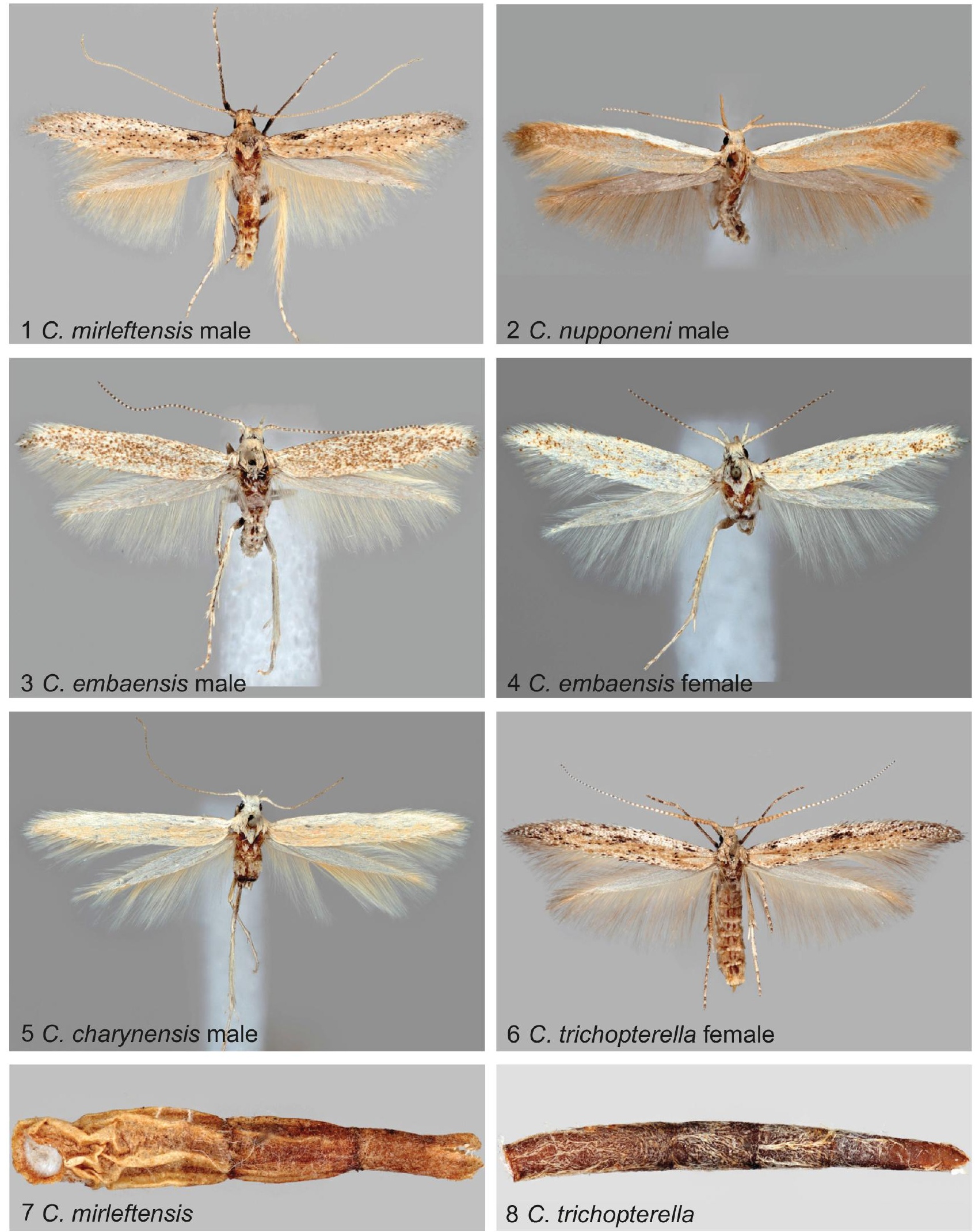

\section{C. trichopterella}

FIGURES 1-8. Adults and larval cases of Coleophora spp. 1-6. Adults. 1. C. mirleftensis sp. nov., § holotype. 2. C. nupponeni sp. nov., đ̊ holotype. 3. C. embaensis sp. nov., ô paratype. 4. C. embaensis sp. nov., + paratype. 5. C. charynensis sp. nov., ô holotype. 6. C. trichopterella Baldizzone, 9. 7-8. Larval cases. 7. C. mirleftensis sp. nov. 8. C. trichopterella Baldizzone. 
Abdominal structures. Tergal latero-posterior bar long, slightly shorter than latero-anterior one. Transverse bar broad, curved, proximal edge weakly sclerotized, indistinct, distal edge thick, medially strongly constricted. Tergal sclerite about $7 x$ longer than wide, weakly sclerotized, covered with 40 conical spines (on T3).

Male genitalia. Gnathos knob transversely oval. Tegumen broad, constricted medially, pedunculus broad. Transtilla narrow, long, bent downwards. Cucullus conical, rather short. Valvula large, outer margin convex, thickened. Sacculus extended nearly to tip of cucullus; ventral margin curved, lateral margin slightly sinuous, ended in short finger-shaped protuberance; dorsal margin concave. Phallotheca a slightly arched tube. Vesica membranous with one large and two to three smaller cornuti grouped together.

Female genitalia. Papillae anales oval, covered with long bristles. Anterior apophyses thick, $1.5 \mathrm{x}$ longer than sterigma, posterior apophyses $1.5 x$ longer than anterior ones. Sterigma transversely rectangular, membranous, covered with bristles, sclerotized only in two short lateral club-shaped patches. T8 weakly sclerotized, subrectangular, medial excavation oval. Ostium bursae and colliculum membranous. Posterior section of ductus bursae slightly curved, transparent, with a medial narrow long sclerotized strip gradually tapering; section around ductus seminalis tightly coiled; anterior section slightly expanded, with two coils and numerous minute spinules. Corpus bursae oval. Signum leaf-like, spine curved with short lateral ridges.

Biology. The larva feeds on the leaves of Salsola sp. (Amaranthaceae) in the spring. The composite leaf case, $12 \mathrm{~mm}$ in length, is constructed of a few hollowed pieces of the host plant. The case is straight or gently curved, yellowish brown, longitudinally wrinkled, trivalved, mouth opening at $45-60^{\circ}$. All larval cases were found on plants growing on sea-shore cliffs.

Distribution. So far only known from south-western Morocco. The type specimens have been collected at light or reared from larvae. The distance between the two collecting localities is $500 \mathrm{~m}$.

Derivation of name. The specific name refers to the collecting locality.

Notes. The resting position of the adult is unusual because the antennae are directed backwards. A few specimens of the type series are small-sized due to withering of the host plant during the rearing process.

\section{Coleophora nupponeni Tabell, sp. nov.}

Barcode Index Number: BOLD:ACT1871

Figs. 2, 9, 14-17, Table 1

Type material. Holotype $\delta^{\prime}$ : Kazakhstan, 430 $08^{\prime} 29^{\prime \prime} \mathrm{N} 67^{\circ} 51^{\prime} 51^{\prime \prime} \mathrm{E}, 185 \mathrm{~m}$, Syr-Darya river, tugai forest,

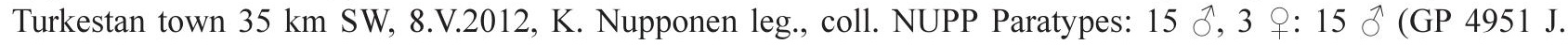
Tabell; DNA sample 21926 Lepid Phyl, abdomen missing in one specimen) same collecting data as in holotype, colls. NUPP and TAB; 3 (GP 5351 J. Tabell, DNA sample 25444 Lepid Phyl; GP 5376 J. Tabell, DNA sample 25445 Lepid Phyl) Tajikistan, Tigrovaya Balka 312 m, 37 $19^{\prime} 961^{\prime \prime} \mathrm{N} 68^{\circ} 27^{\prime} 475^{\prime \prime} \mathrm{E}, 3 . \mathrm{V} .2014$, T. Nupponen \& R. Haverinen leg., colls. NUPP and TAB.

Diagnosis. In external appearance C. nupponeni sp. nov. resembles C. algeriensis Toll, 1952, C. schmidti Toll, 1960, C. eurasiatica Baldizzone, 1989 and C. lonchodes (Falkovitsh, 1994), which all share the yellowish or reddish brown forewing with a white costal stripe. Conspicuously longer labial palpi distinguish $C$. nupponeni from the aforesaid species. In the male genitalia of $C$. nupponeni the stout seta at costa is characteristic and separates the species from all close relatives. In the female genitalia the dense bristles at the distal margin of the sterigma and stud-shaped spinules in the ductus bursae distinguish C. nupponeni from related taxa.

Molecular diagnosis. The DNA barcodes were 6.76-11.74 \% divergent from the other related species (Table 1).

Description. Wingspan 15.5-17.0 mm. Head, thorax and tegula pale reddish brown. Antenna white, annulated with pale reddish brown, scape pale reddish brown. Labial palpus long, straight, pale reddish brown. Forewing reddish brown with white costal stripe to $4 / 5$, broad at base and gradually tapering towards apex, fringe concolorous. Hindwing pale grey, fringe reddish brown. Abdomen pale grey, slightly lustrous.

Abdominal structures. Latero-posterior bar half length of latero-anterior one. Transverse bar broad, proximal edge straight, only medially sclerotized, distal edge strongly curved. Tergal sclerite 6-7x longer than wide, weakly sclerotized, covered with 30 conical spines (on T3). In female transverse bar narrow, proximal edge thin, straight, distal edge thick, medially constricted. 


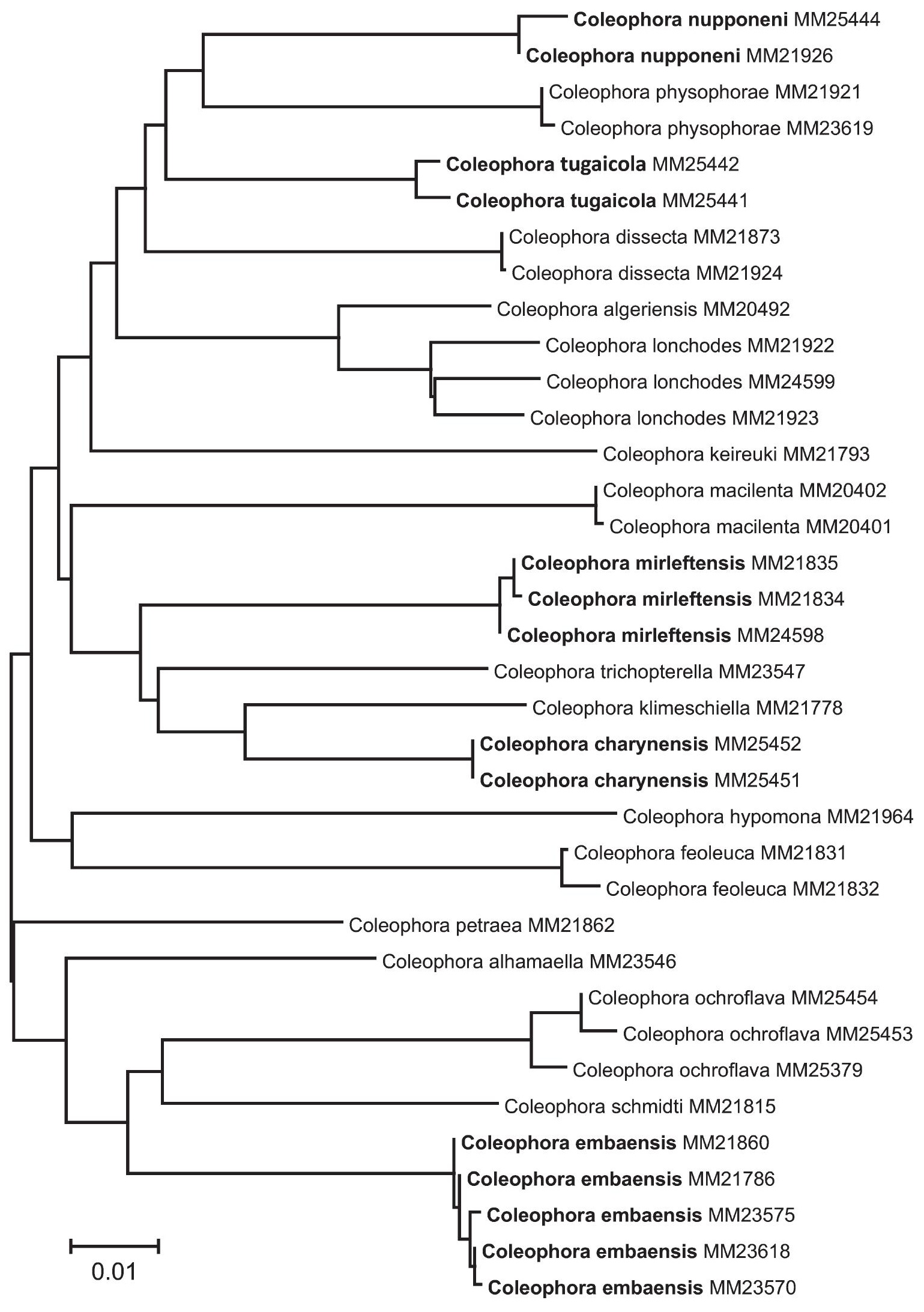

FIGURE 9. Neighbor-joining tree of the barcoded taxa of the $C$. poecilella species group, based on sequences of $C O I$ gene. 


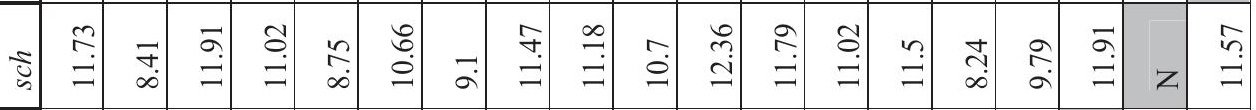

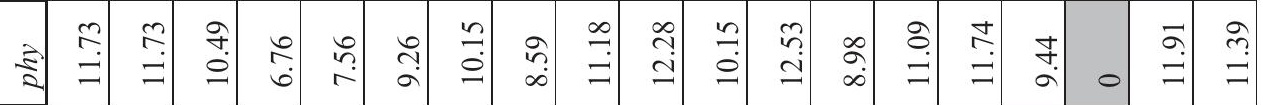

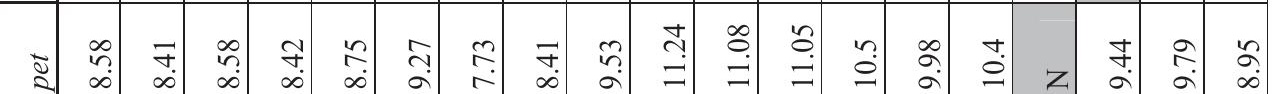
亏)

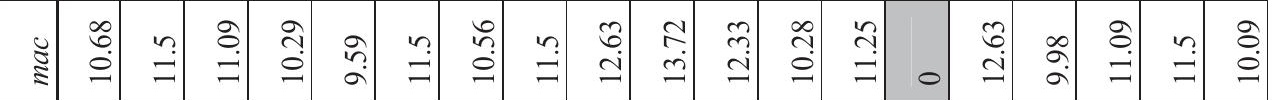
₹

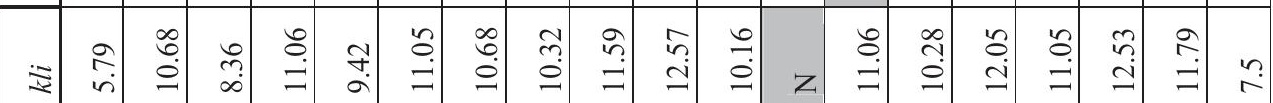
₹

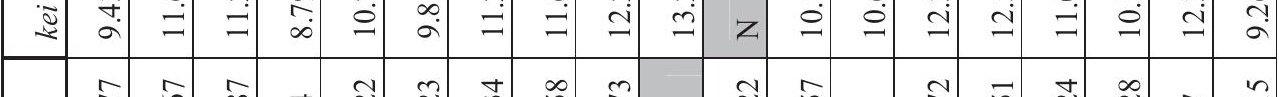

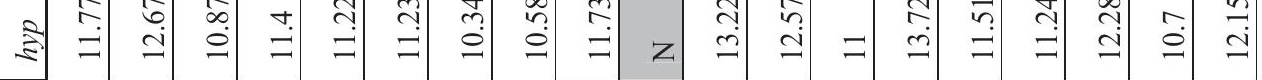
\&

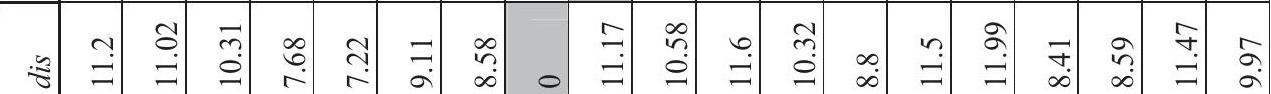

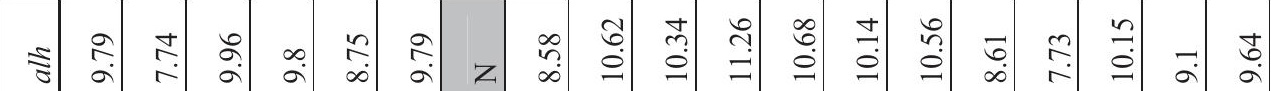

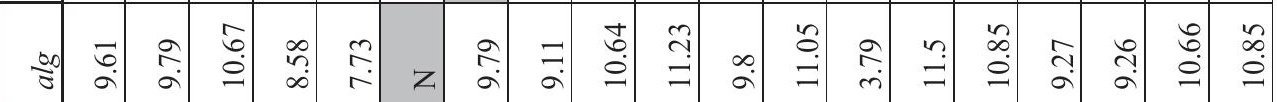

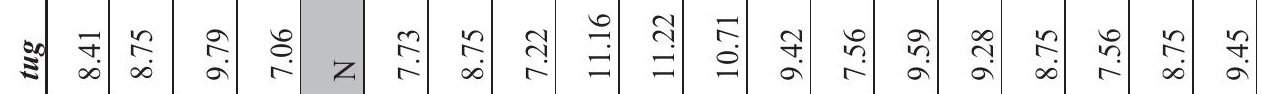

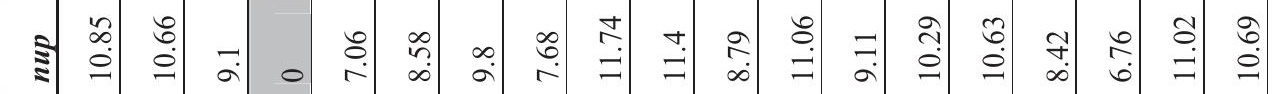
茥 音

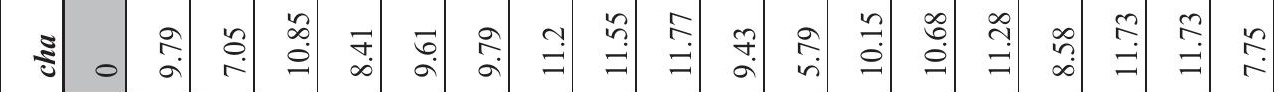
要

\begin{tabular}{|c|c|c|c|c|c|c|c|c|c|c|c|c|c|c|c|c|c|}
\hline 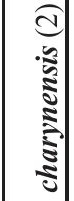 & 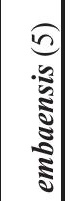 & ? & 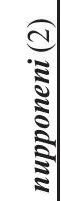 & $\begin{array}{l}\text { : } \\
\text { : } \\
\text { : } \\
\text { : }\end{array}$ & 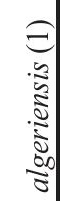 & 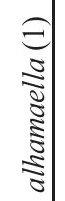 & 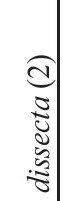 & 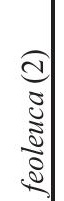 & 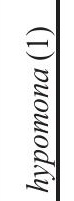 & 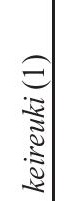 & 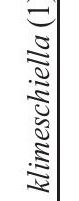 & 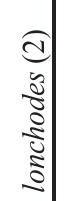 & בป & : & \begin{tabular}{l} 
: \\
\multirow{8}{*}{} \\
:
\end{tabular} & 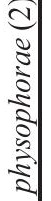 & \\
\hline
\end{tabular}




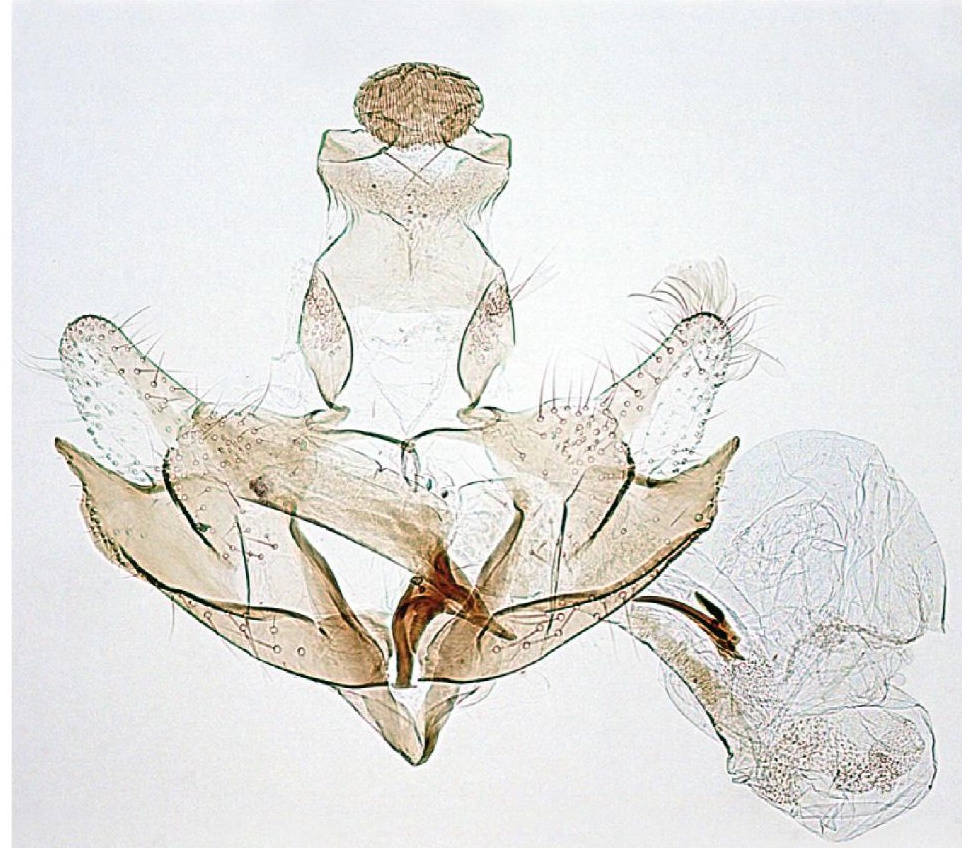

10 Coleophora mirleftensis

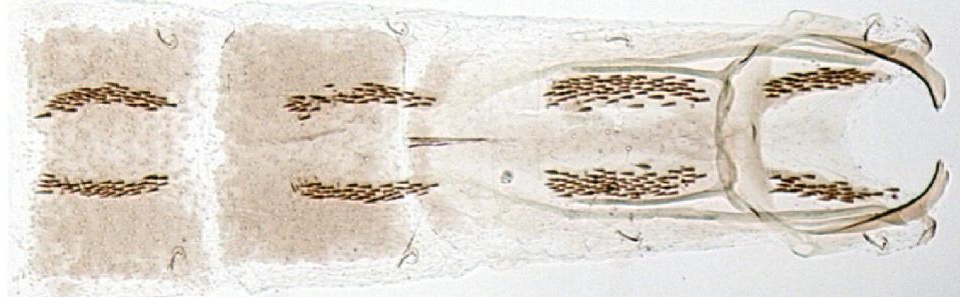

11 male

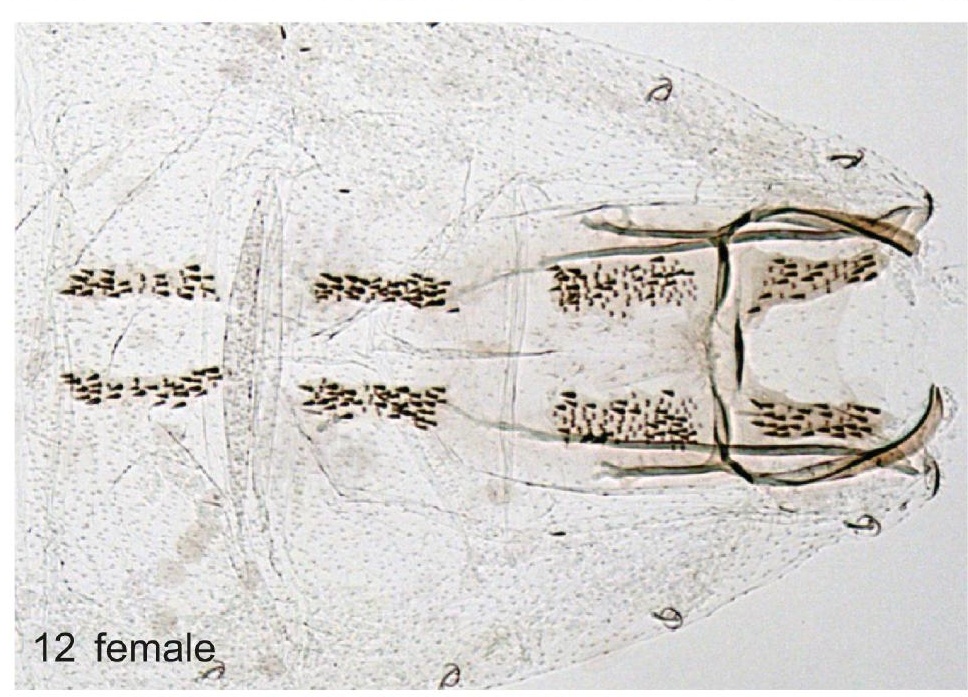

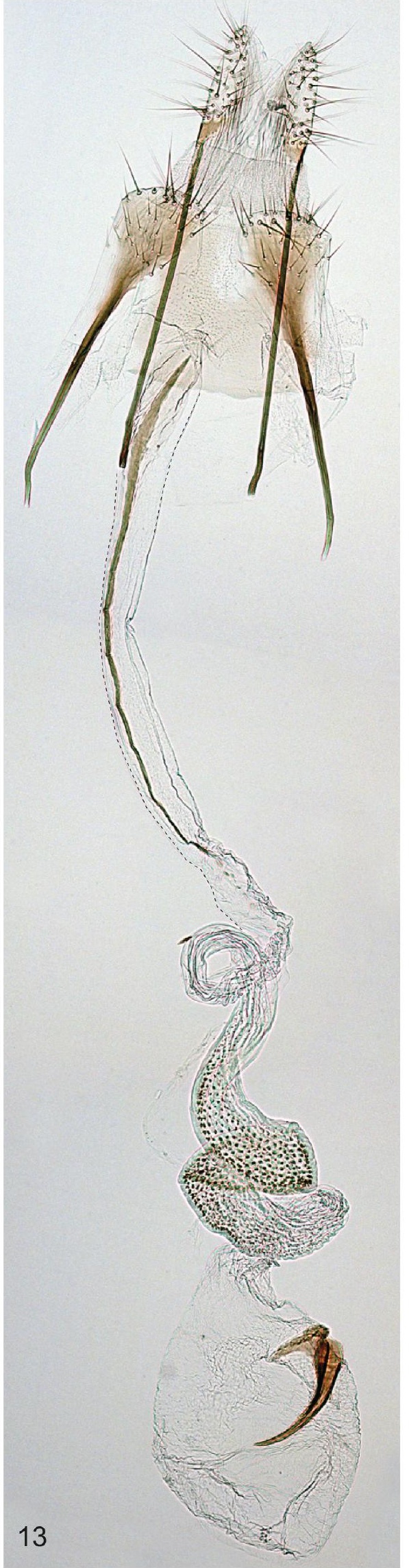

13

FIGURES 10-13. C. mirleftensis sp. nov. 10. đ̊ genitalia, GP 5063 J. Tabell. 11. đ̊ abdomen. 12. + abdomen. 13. + genitalia, GP 5467 J. Tabell. 


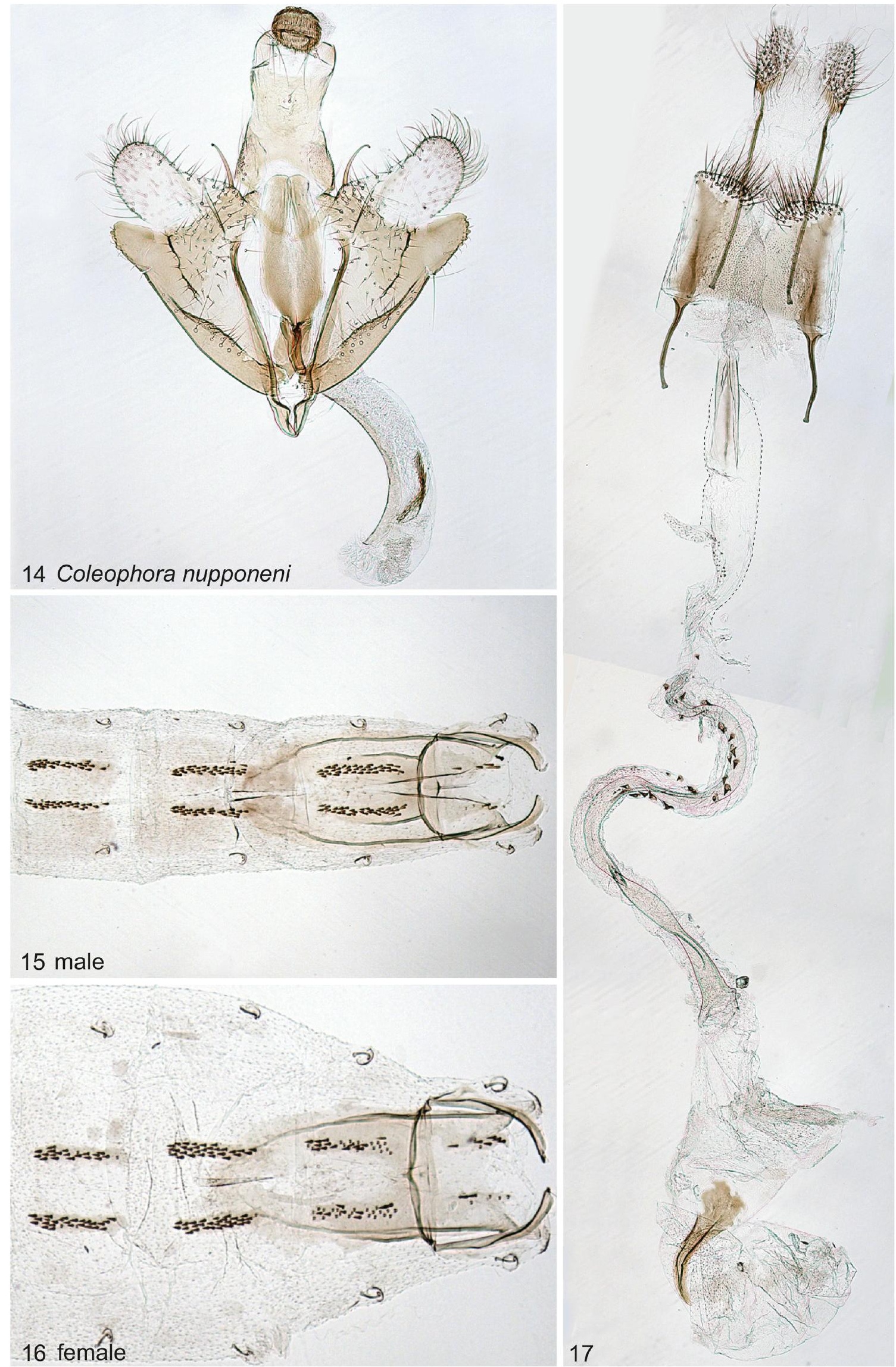

FIGURES 14-17. C. mupponeni sp. nov. 14. $\precsim$ genitalia, GP 4951 J. Tabell. 15. $ð$ abdomen. 16. $q$ abdomen. 17. $q$ genitalia, GP 5351 J. Tabell. 
Male genitalia. Gnathos knob suborbicular. Tegumen slightly constricted medially, pedunculus short. Transtilla finger-shaped, bent down. Cucullus broadly rounded, stubby, not extended beyond apex of sacculus. Costa slightly concave, basally bulged and with single thick seta. Valvula triangular, outer margin slightly sinuous, thickened, lined with bristles. Sacculus broad; ventral margin very oblique, lateral margin short, rounded, with a few small nodules, dorsal margin concave, horizontal. Phallotheca a conical tube, medially membranous (ventral view). Vesica membranous, with curved bundle of several short spiniform cornuti.

Female genitalia. Papillae anales conical, covered with long bristles. Anterior apophyses shorter than sterigma, incurved, posterior apophyses $2.5 \mathrm{x}$ longer than anterior ones. Sterigma rectangular, membranous, apex densely covered with bristles; sclerotized only in two lateral sickle-shaped patches, inner margins jagged. T8 weakly sclerotized. Ostium bursae and colliculum membranous. Posterior section of ductus bursae straight, with a medial sclerotized short strip; medial section coiled, with scattered stud-like spinules; anterior section devoid of spinules, slightly expanded. Corpus bursae oval. Signum thorn-like, spine slightly curved, with two thin ridges, base without ridges.

Biology. Immature stages and larval host plant are unknown. The habitats are tugai forests on sandy riversides, with typical tugai vegetation such as Populus euphratica Oliv. and Salix (Salicaceae), Phragmites (Poaceae), Elaeagnus (Elaeagnaceae), etc. (see also Biology under C. tugaicola). The moth is nocturnal and comes to light.

Distribution. So far the new taxon is known from two localities in the Syr-Darya valley in southern Kazakhstan, and by the upper Amu-Darya river in south-western Tajikistan.

Derivation of name. The species is dedicated to Kari Nupponen, a Finnish expert on several Lepidoptera groups and the collector of most of the type material presented here.

\section{Coleophora embaensis Tabell, sp. nov.}

Barcode Index Number: BOLD:ACT3652

Figs. 3,4, 9, 18-21, Table 1

Type material. Holotype $\sigma^{\lambda}$ (GP 4968 J. Tabell, DNA sample 23575 Lepid Phyl): Kazakhstan, 48 $55^{\prime} 29^{\prime \prime} \mathrm{N}$

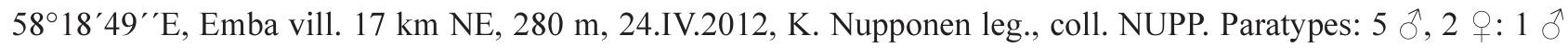
(DNA sample 23618 Lepid Phyl), 1 (GP 5361 J. Tabell) same collecting data as in holotype, colls. NUPP and

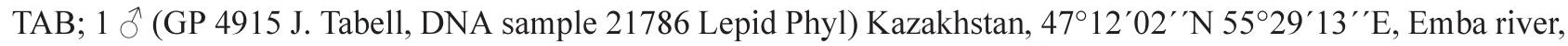
45 m, Besbai village 2 km E, 11.V.2011, K. Nupponen leg., coll. NUPP; 2 đ same collecting data, but 19.IV.2013, coll. NUPP; 1 ð (GP 5161 J. Tabell, DNA sample 23570 Lepid Phyl) SW Kazakhstan, $44^{\circ} 01^{\prime} 04^{\prime \prime} \mathrm{N} 53^{\circ} 25^{\prime} 46^{\prime \prime}$ E, 240 m, Sai-Utes vill. 40 km S, Syndy, 6.IV.2013, K. Nupponen leg., coll. TAB; 1 q (DNA sample 21860 Lepid Phyl) Kazakhstan, $47^{\circ} 27^{\prime} 24^{\prime \prime} \mathrm{N} 55^{\circ} 06^{\prime} 45^{\prime \prime} \mathrm{E}$, Aktolagai chalk hills, 95 m, Emba river 40 km NW, 15-V-2010, K. Nupponen leg, coll. NUPP.

Diagnosis. In genitalia $C$. embaensis sp. nov. is close to $C$. ochroflava Toll, 1961. In the male genitalia of $C$. embaensis cornuti are absent, the valvula is rounded and the cucullus is conical, whereas in $C$. ochroflava the cornuti are grouped into robust bundle, the valvula is triangular and the cucullus is parallel-sided. In the female genitalia of $C$. embaensis the sclerotization of the sterigma in the proximal part is larger, the apophyses anteriores are thicker and the ductus bursae has two twists and several conical dark spines; in C. ochroflava the ductus bursae is straight without conical spines.

Molecular diagnosis. Five specimens of $C$. embaensis were sequenced, resulting in $658 \mathrm{bp}(\mathrm{n}=2), 636 \mathrm{bp}$ $(\mathrm{n}=2)$ and $611 \mathrm{bp}(\mathrm{n}=1)$ DNA barcode fragments. The resultant sequences revealed 7.74-12.67 \% divergences between $C$. embaensis and the other barcoded species (Table 1). The barcodes of C. embaensis displayed $0.16 \%$ intraspecific variation.

Description. Wingspan 9-11 mm. Head pale fuscous. Antenna white, annulated with pale brown. Scape pale fuscous. Labial palpus pale fuscous mixed with white; tufted second segment $1.5 \mathrm{x}$ longer than third segment. Thorax pale fuscous; tegula mixed with whitish grey scales. Forewing mottled, creamy white, densely covered with ochreous brown-tipped, pale fuscous scales, in female scales paler and more sparse, fringe whitish grey to pale brown. Hindwing pale grey, fringe whitish grey. Abdomen whitish grey, slightly lustrous.

Abdominal structures. Latero-posterior bar short, 2/5-2/7x length of latero-anterior one. Transverse bar straight, proximal edge thin, medially slightly convex, distal edge thick, medially strongly constricted. Tergal sclerite $2.5-3.5 \mathrm{x}$ longer than wide, covered with 40 conical spines (on T3). 

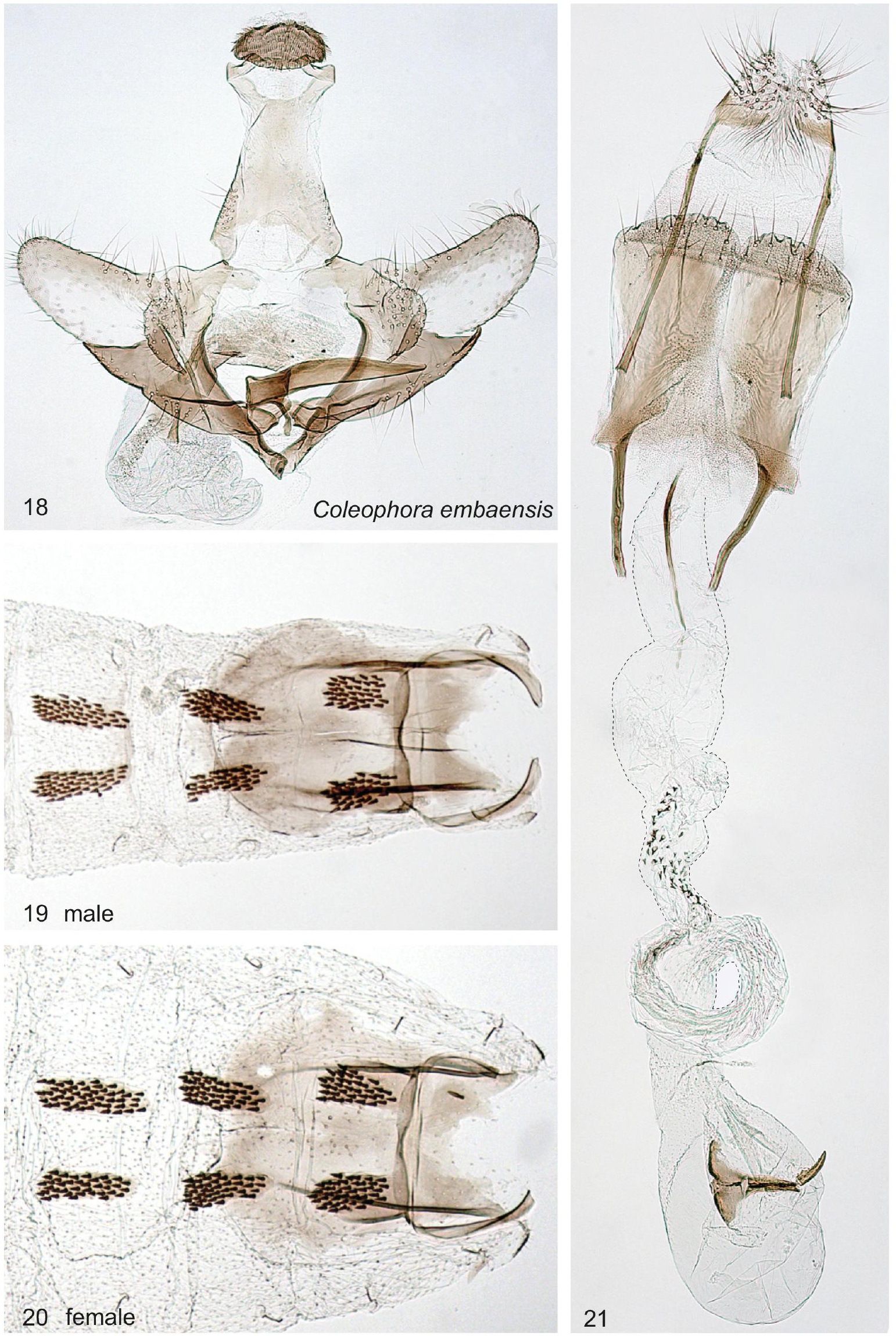

19 male

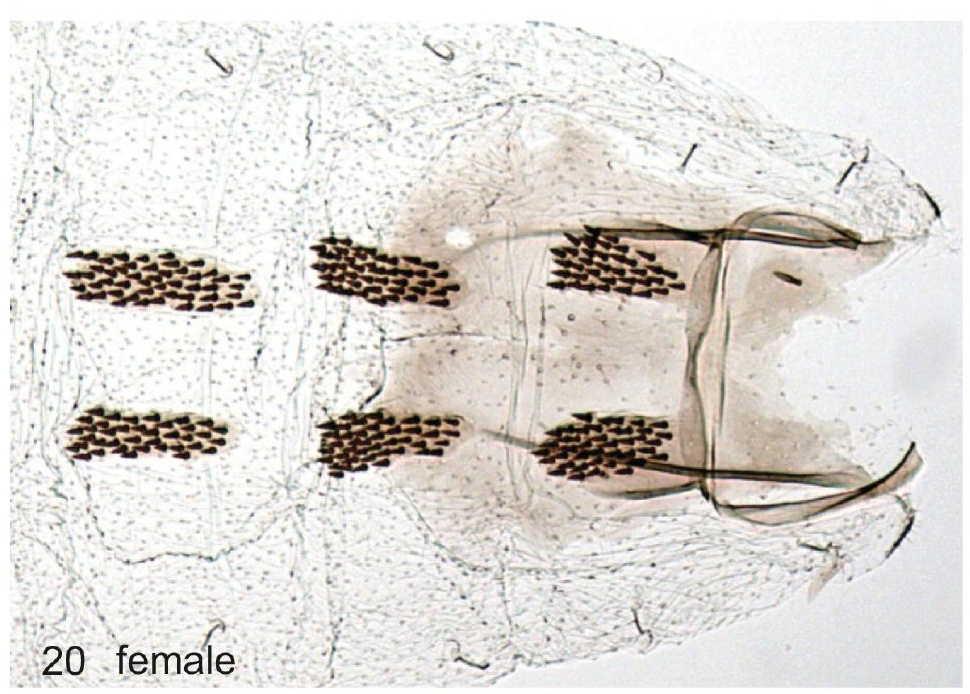

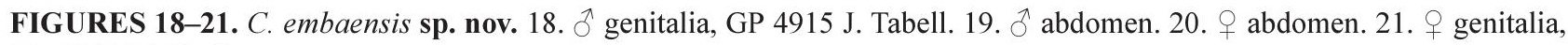
GP 5361 J. Tabell. 
Male genitalia. Gnathos knob transversely oval, broad. Tegumen conical, pedunculus short. Transtilla transversely straight, stubby. Cucullus conical. Costa basally slightly bulged. Valvula narrower than cucullus, outer margin distinctly delineated and evenly rounded, lined with several bristles. Sacculus simple; ventral margin slightly convex, terminating in acute angle, dorsal margin slightly concave, horizontal. Phallotheca narrow, well sclerotized, tubular, apical half conical. Vesica membranous, cornuti absent.

Female genitalia. Papillae anales conical, covered with long bristles. Anterior apophyses thick, half as long as sterigma, posterior apophyses twice as long as anterior ones. Sterigma quadrate, distal part covered with bristles; proximal margin concave; caudal margin rounded; medial excavation as long as sterigma, distally trough-shaped, proximally rounded. Ostium bursae and colliculum membranous. Ductus bursae transparent; posterior section twisted once, with a medial sclerotized strip about as long as anterior apophysis; section around ductus seminalis twisted, with about 40 small, conical spines; anterior section with one large coil and scattered minute spinules. Corpus bursae oval. Signum elongate, fluke-shaped, spine long with serrated ridge.

Biology. The immature stages and larval host plant are unknown. The species inhabits chalk steppes and cliffs in western Kazakhstan. The habitat of the holotype and seven paratypes is illustrated by Nupponen (2014: p. 250, Fig. 1). The flight period starts in early April and extends into mid-May. The moth is nocturnal and comes to light.

Distribution. So far the new taxon is known from few localities in western and south-western Kazakhstan.

Derivation of name. The specific name refers to the river Emba, which flows in the vicinity of the collecting localities.

\section{Coleophora charynensis Tabell, sp. nov.}

Barcode Index Number: BOLD:ADD3578

Figs. 5, 9, 22-23, Table 1

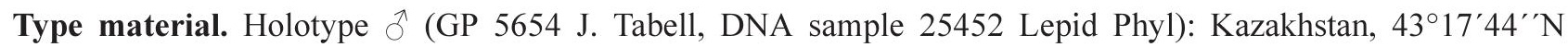

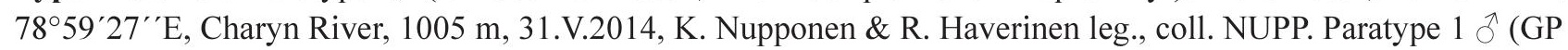
5337 J. Tabell, DNA sample 25451 Lepid Phyl) same collecting data as in holotype, coll. NUPP.

Diagnosis. In male genitalia $C$. charynensis sp. nov. is close to $C$. trichopterella and C. mirleftensis sp. nov. A large fold at the outer margin of valvula is characteristic and distinguishes the new taxon from all close relatives.

Molecular diagnosis. Both type specimens were sequenced successfully, resulting in identical full 658 bp DNA barcode fragments. The sequences revealed 5.79-11.77\% divergences from other barcoded taxa (Table 1). Compared to C. trichopterella $(\mathrm{n}=1)$ and C. mirleftensis $(\mathrm{n}=3)$ the barcode gap is $7.75 \%$ and $7.05 \%$, respectively.

Description. Wingspan 12.5-13.0 mm. Head white. Antenna unicolorous pale ocherous. Scape white. Labial palpus slightly ascending, white, not tufted, second segment $1.5 \mathrm{x}$ longer than third segment. Thorax and tegula white with mixed pale ochre. Forewing pale ochre, costa broadly white, fringes whitish grey. Hindwing pale grey, fringe whitish grey.

Abdominal structures. Latero-posterior bar thick, 2/3x length of latero-anterior one. Transverse bar slightly concave, proximal edge thin, sclerotized only medially, distal edge very thick, medially strongly constricted and bulged. Tergal sclerite $6 x$ longer than wide, covered with 45 conical spines (on T3).

Male genitalia. Gnathos knob transversely oval. Tegumen moderately short, medially slightly constricted, pedunculus long. Transtilla elongate, wedge-shaped, bent downwards. Cucullus thimble-shaped, narrow, not extended to tip of sacculus. Valvula broader than cucullus, weakly delineated, outer margin with large elongate fold. Sacculus elongate, bifurcate; ventral margin oblique, slightly convex, terminating in small triangular protuberance; lateral margin short, concave, dorsal process blunt, triangular, exceeding apex of cucullus; dorsal margin convergent with lower margin of cucullus. Phallotheca a well sclerotized elongate tube. Vesica partly well sclerotized, with two long cornuti grouped with a basal plate.

Female genitalia. Unknown.

Biology. The immature stages and larval host plant are unknown. The specimens came to light at night. The habitat is a steep river canyon with rocky steppe slopes on both sides.

Distribution. So far the new species is only known from the type locality in the Charyn River canyon, southeastern Kazakhstan. 
Derivation of name. The specific name refers to Charyn River, which flows in the vicinity of the collecting locality.
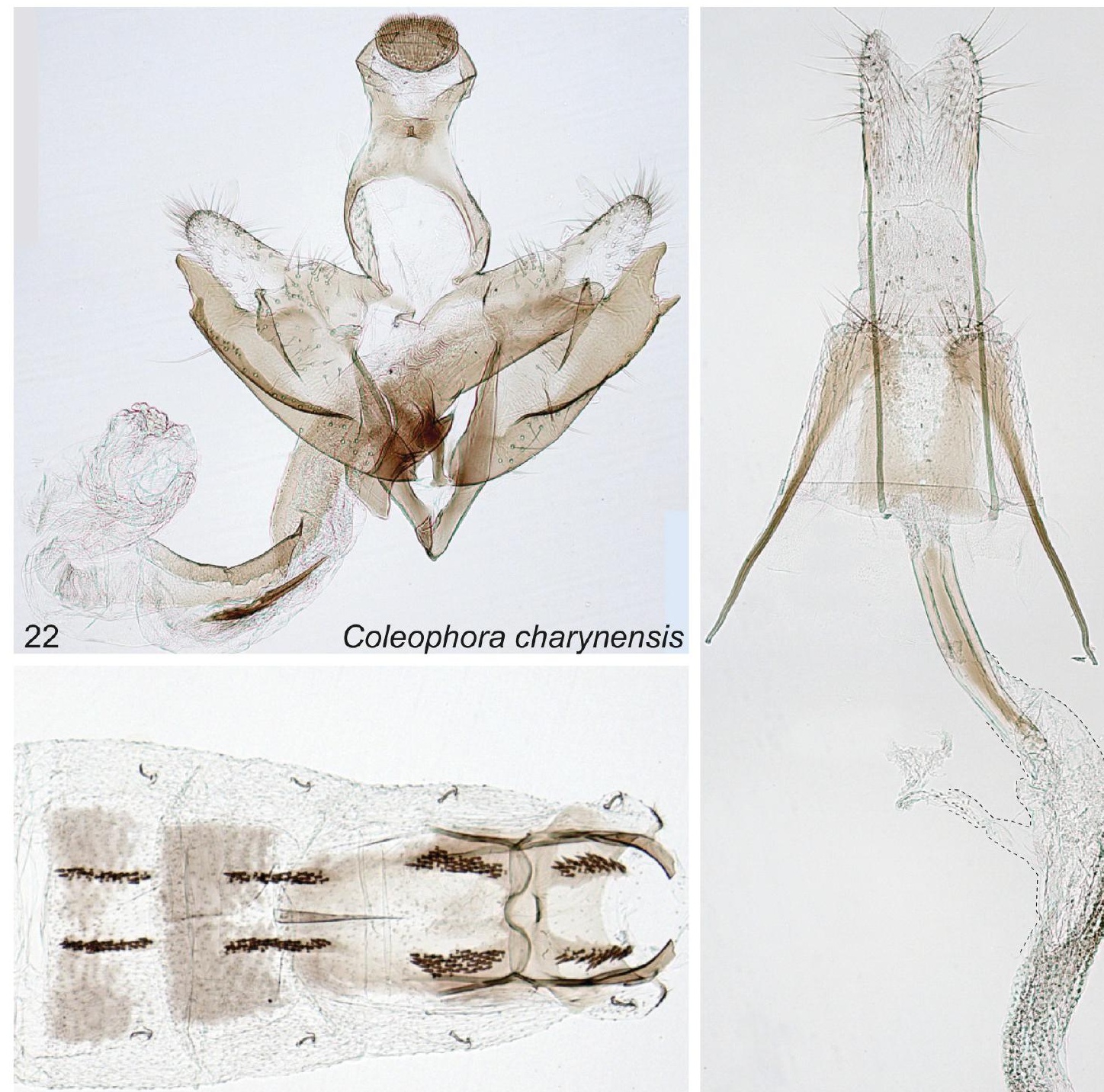

23 male

Coleophora charynensis

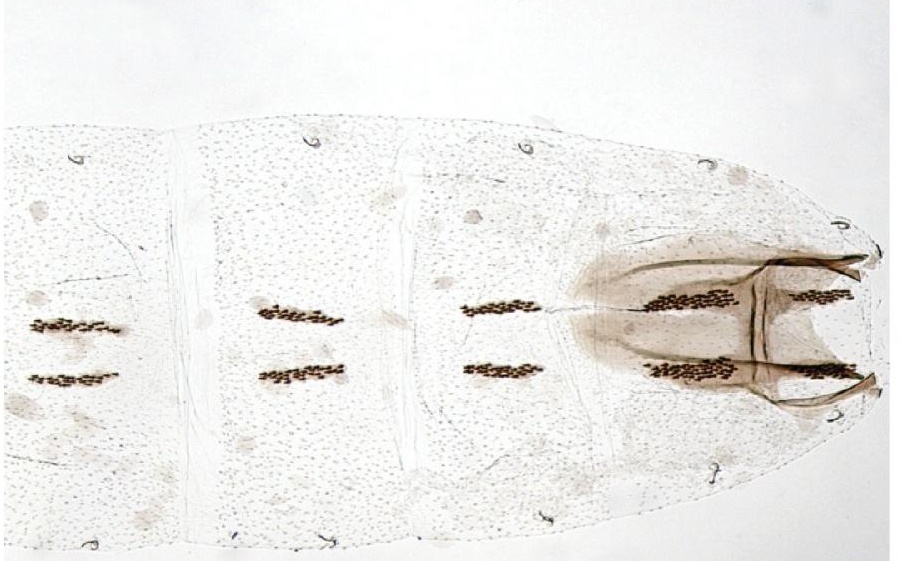

24 female

Coleophora trichopterella

Coleophora trichopterella 25

FIGURES 22-25. Coleophora spp. 22-23. C. charynensis sp. nov. 22. ô genitalia, GP 5654 J. Tabell. 23. $\widehat{o}$ abdomen. $24-25$. C. trichopterella Baldizzone. 24. $\odot$ abdomen. 25. $~$ genitalia, GP 5241 J. Tabell. 
Type material. Holotype + (GP 5331 J. Tabell, DNA sample 25441 Lepid Phyl): Tajikistan, Tigrovaya Balka 312

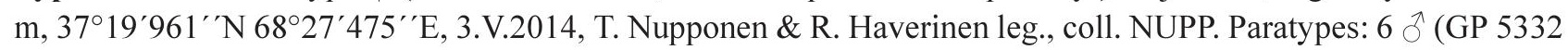
J. Tabell, DNA sample 25442 Lepid Phyl), 1 ㅇ same collecting data as in holotype, colls. NUPP and TAB.

Diagnosis. Coleophora. tugaicola sp. nov. is characterized by four white stripes on the costal half of the pale brown forewings. In male genitalia C. tugaicola is closer to C. algeriensis Toll, 1952, C. dissecta (Falkovitsh, 1989), C. physophorae (Falkovitsh, 1994), C. lonchodes (Falkovitsh, 1994) and C. hypoxantha (Falkovitsh, 1982). A combination of the shape of the valvula, cornuti, and apical half of the sacculus distinguishes $C$. tugaicola from the aforementioned species. In female genitalia the short feather-shaped formation in the ductus bursae is characteristic.

Molecular diagnosis. Two type specimens ( $1 \delta$ and 1 क $)$ were sequenced, resulting in $658 \mathrm{bp}$ and $483 \mathrm{bp}$ DNA barcode fragments. The sequences showed 7.06-11.22\% divergences between $C$. tugaicola and the other barcoded taxa (Table 1).

Description. Wingspan 11.0-12.5 mm. Head, thorax and tegula white. Antenna whitish grey, in male apical half annulated with pale brown, scape whitish grey. Labial palpus white, not tufted, second segment as long as third. Forewing pale brown mixed with white scales, costal half with four longitudinal white broad stripes. Costal fringes white, dorsal fringes pale brown, apical fringes brown. Hindwing and fringe pale grey. Abdomen greyish white, slightly lustrous. The worn condition of the type material precludes a more accurate description.

Abdominal structures. Latero-posterior bar half as long as latero-anterior one. Transverse bar broad, straight, proximal edge unsclerotized, distal edge thick, medially convex. Tergal sclerite about $7 \mathrm{x}$ longer than wide, covered with 40 conical spines on $\mathrm{T} 3$.

Male genitalia. Gnathos knob transversely oval. Tegumen moderately broad, medially slightly constricted, pedunculus broad. Transtilla narrow, finger-shaped, slightly bent downwards. Cucullus conical, stubby, broad, slightly extended beyond tip of sacculus. Valvula moderately broad, outer margin weakly delineated, ventral margin with elongate fold. Sacculus simple; ventral margin slightly convex, apically lined with a few small nodules, terminating in acute angle; dorsal margin slightly concave, horizontal. Phallotheca well sclerotized elongate tube with a small medial, shallow cleft. Vesica partly well sclerotized, with a narrow slightly curved chain of several spiniform cornuti.

Female genitalia. Papillae anales oval, densely covered with long bristles. Anterior apophyses slightly shorter than sterigma, posterior apophyses twice as long as anterior ones. Sterigma rectangular, membranous, sclerotized only in two elongate lateral club-shaped patches; proximal margin membranous, indistinct; caudal margin rounded, densely edged with bristles. T8 weakly sclerotized, proximal margin convex. Ostium bursae and colliculum membranous. Posterior section of ductus bursae transparent, with a sclerotized feather-liked band; medial section with about 15 conical spines of different size; anterior section coiled once, expanded into oval corpus bursae. Signum thornlike; spine curved, with two shallow ridges; base with two strongly sclerotized ridges.

Biology. Immature stages and larval host plant are unknown. The specimens came to light at night. The habitat is a tugai forest (Fig. 34). Tugai habitats are riparian forests or woodlands, largely dependent on floods and groundwater. They occur in semi-arid and desert climates in central Asia (see also Biology under C. nupponeni).

Distribution. So far the new species is only known from the type locality in Tajikistan.

Derivation of name. The specific name refers to the collecting habitat, tugai forest.

Remarks. The male and female of this species were associated by their identical barcodes and the same collection locality and time.

\section{Coleophora trichopterella Baldizzone, 1985}

Figs. 6, 8, 9, 24-25, Table 1

Material examined. $3 \widehat{\gamma}$ (GP 5197 J. Tabell, DNA sample 23547 Lepid Phyl), 3 q (GP 5241 J. Tabell) Spain, Granada, Cüllar 5.5 km N, 870 m, Suaeda sp. 12.IV.2014, e[x].1[arva]. IX.2014, J. Tabell leg. 

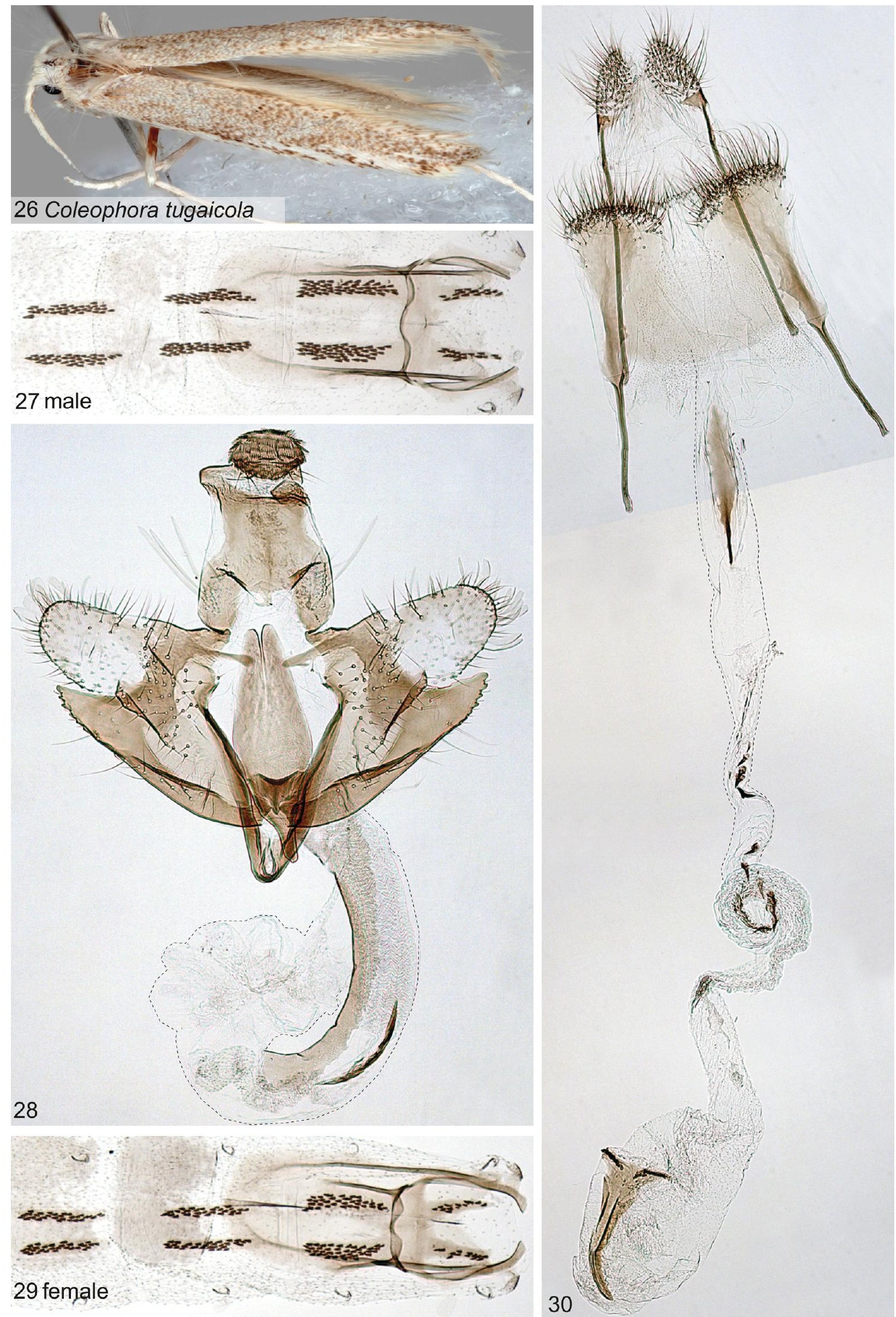

28

27 male
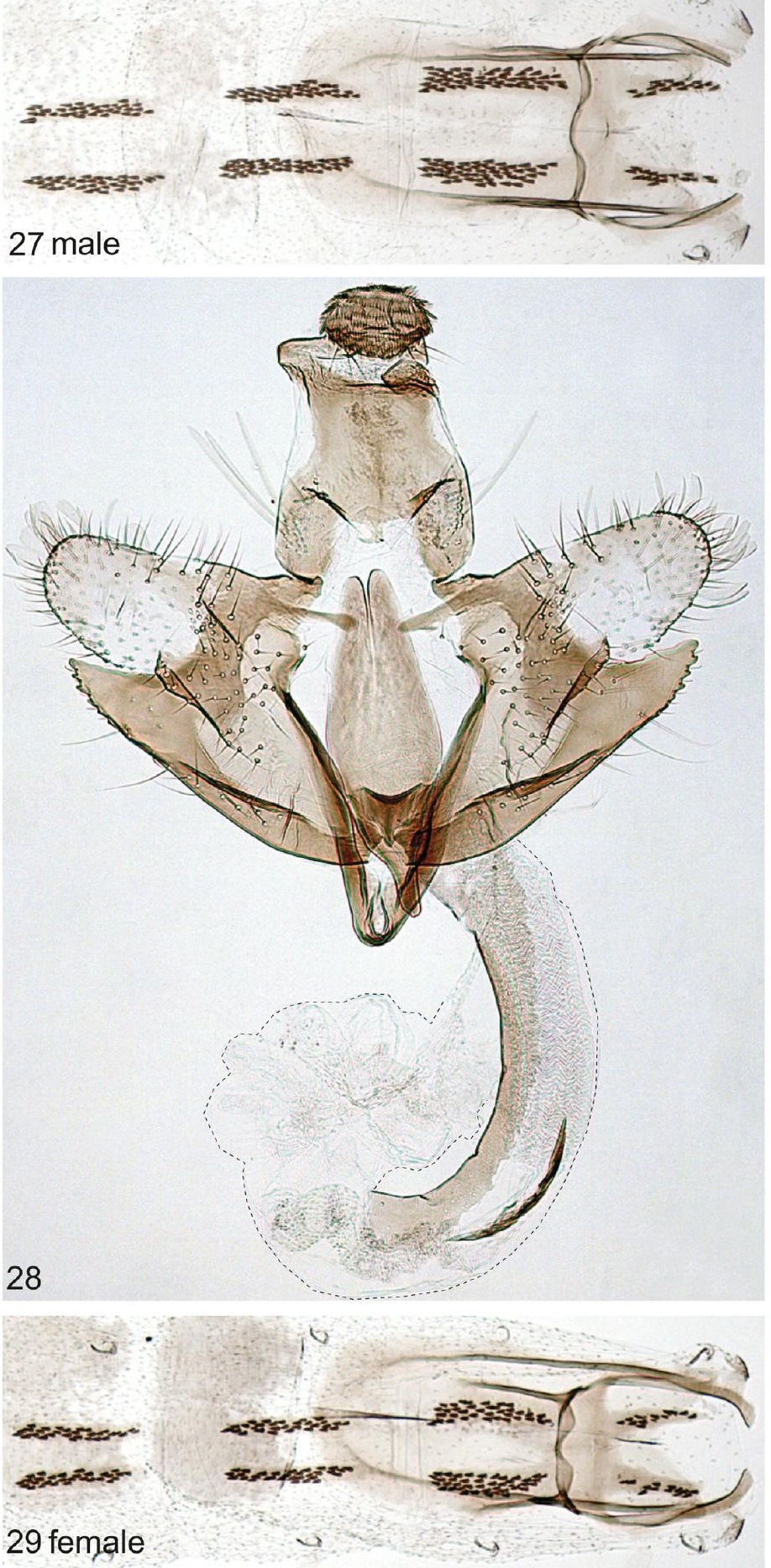

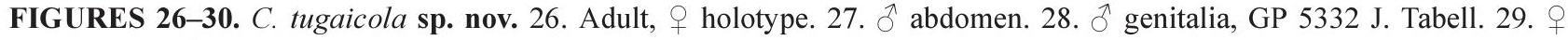
abdomen. 30. 9 genitalia, GP 5331 J. Tabell. 

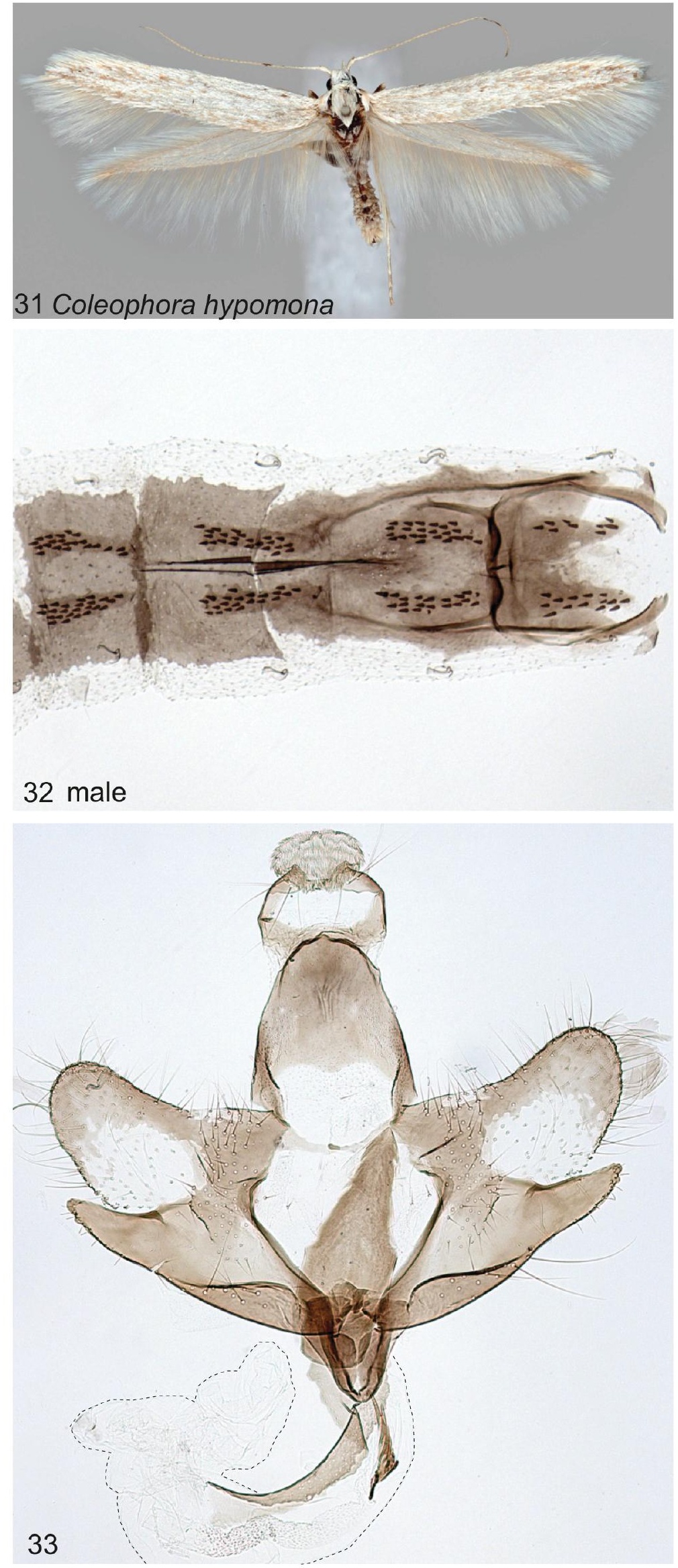

FIGURES 31-33. C. hypomona (Falkovitsh). 31. Adult. 32. 0 abdomen, GP 5153 J. Tabell. 33. $\delta$ genitalia. 
Abdominal structures. Latero-posterior bar indistinct. Transverse bar narrow, both edges distinctly sclerotized. Tergal sclerite narrow, $6 x$ longer than wide, covered with 30 conical spines (on T3).

Female genitalia. Papillae anales oval, covered with long bristles. Anterior apophyses as long as sterigma, posterior apophyses twice longer than anterior ones. Sterigma trapezoid, membranous, sclerotized only in two elongate lateral club-shaped patches; proximal margin membranous, indistinct; caudal margin rounded, edged with bristles. T8 sclerotized, subrectangular, with deep emargination, proximal margin concave. Ostium bursae and colliculum membranous. Posterior section of ductus bursae narrow, with a medial sclerotized band; section around ductus seminalis posteriorly slightly swollen, transparent, anteriorly winding, densely covered with small spinacles; anterior section slightly sclerotized, expanded. Corpus bursae oval, small. Signum leaf-like; spine curved, with two shallow ridges.

Biology. The larva feeds on the leaves of Suaeda sp. (Amaranthaceae) in the spring. The composite leaf case, $10.5-11.5 \mathrm{~mm}$ in length, is constructed of several hollowed pieces of the host plant. The case is gently curved, thin, brownish grey, smooth or longitudinally gently wrinkled, trivalved, mouth opening at $80-85^{\circ}$. The adults emerge in September-October after a summer diapause.

Remarks. The description of $C$. trichopterella is based on four male specimens collected in southern Spain (Baldizzone 1985). The biology and female adult have remained unknown until now. Three male and three female adults emerged from cases found on Suaeda sp., and this enables to describe the female genitalia and illustrate the larval case.

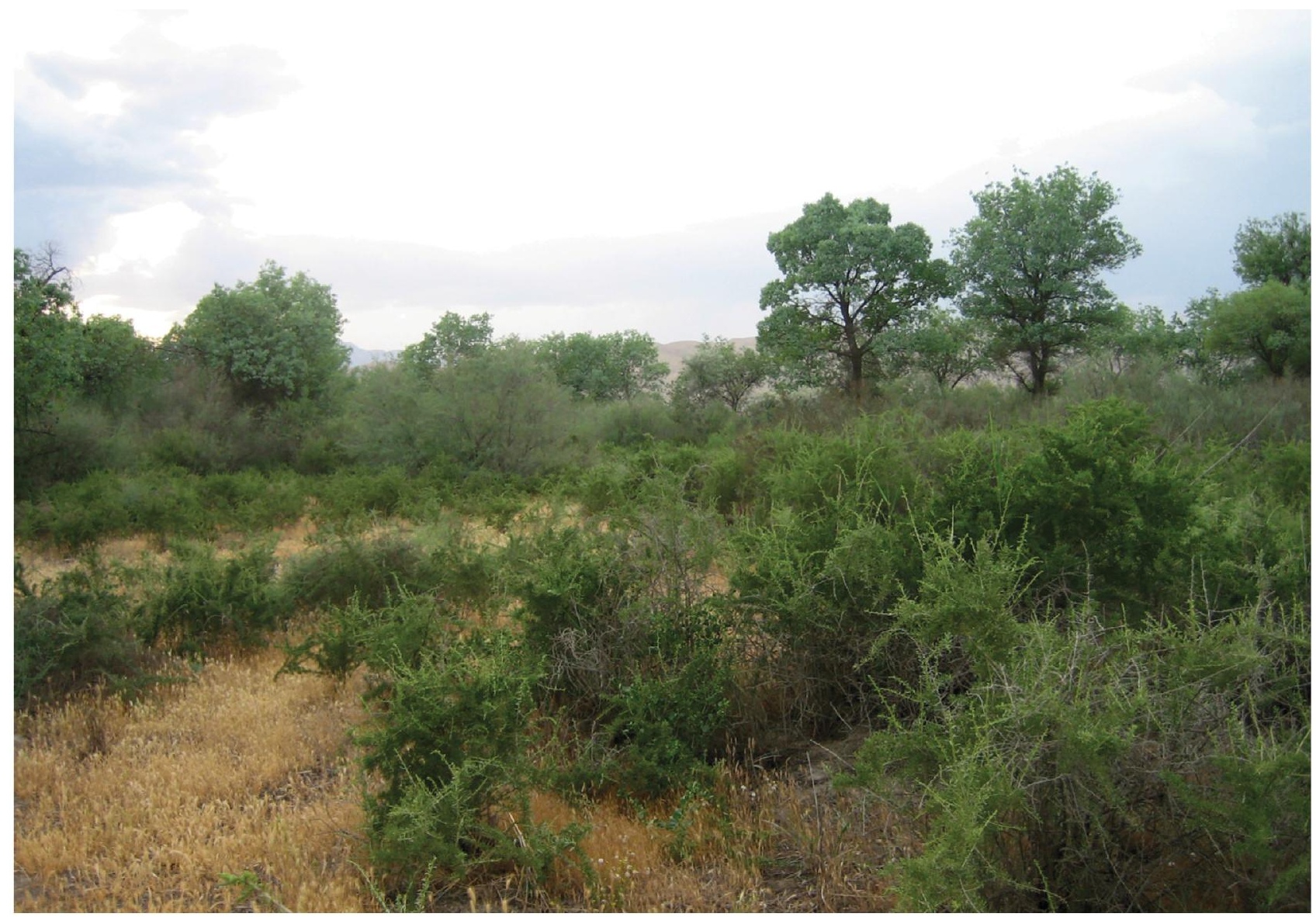

FIGURE 34. Type locality of $C$. tugaicola sp. nov. SW Tajikistan, Tigrovaya Balka, 3.V.2014, tugai forest habitat. Photo by T. Nupponen.

Coleophora hypomona (Falkovitsh, 1979)

Figs. 9, 31-33, Table 1

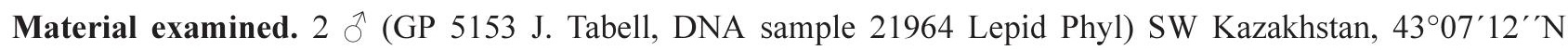
$54^{\circ} 11^{\prime} 27^{\prime \prime}$ E, Akkuduk vill[age]. 20 km N, 80 m, Karynzharyk sands, Tynyshtyk, 14.IV.2013, K. Nupponen leg. 


\section{Additions to original description.}

Abdominal structures. Latero-posterior bar half as long as of latero-anterior one. Transverse bar straight, proximal edge sclerotized only medially, distal edge thick, medially strongly constricted. Tergal sclerite $5 x$ longer than wide, covered with 20-25 conical spines (on T3).

Male genitalia. Gnathos knob transversely oval. Tegumen conical, pedunculus short. Transtilla wedge-shaped. Cucullus conical, stubby, broad, apically and dorsally sclerotized. Costa slightly concave, not bulged. Valvula narrow, $2 \mathrm{x}$ higher than wide, covered with bristles, outer margin medially concave, ventral margin distinctly delineated. Sacculus narrow, not extended beyond apex of cucullus; ventral margin curved, slightly concave, terminating in elongate blunt protuberance, apex with few small nodules; dorsal margin slightly concave, horizontal. Phallotheca conical, well sclerotized tube. Vesica partly well sclerotized, about five cornuti grouped into a thorn-like bundle.

Remarks. Coleophora hypomona was described from Uzbekistan and the description is based exclusively on female specimens (Falkovitsh 1979). The male adult has been unknown until now. The identification of male specimens in this study is based on forewing coloration (white with indistinct stripes), which is unique in the $C$. poecilella species group.

\section{Acknowledgements}

We thank Giorgio Baldizzone for discussing the status of some new species, Kari Nupponen for allowing to study his specimens and Juha Tyllinen for photographing the adults. We thank the Kone Foundation, Finnish Cultural Foundation and the Academy of Finland for support in barcoding through the Finnish Barcode of Life initiative. We are also grateful to the staff of the Canadian Centre for DNA barcoding for sequencing the samples and continuous help in managing our BOLD records.

\section{References}

Baldizzone, G. (1985) Contribution à la connaissance des Coleophoridae. XLII. Sur quelques Coleophoridae d'Espagne (Première partie: Description de nouvelles espèces). Nota lepidopterologica, 8, 203-241. Available from: https:// www.biodiversitylibrary.org/item/128825\#page/223/mode/1up (Accessed 5 Jun. 2018)

Falkovitsh, M.I. (1972) [New species of casebearers (Lepidoptera, Coleophoridae) bred from larvae in the Kysylkum Desert]. Trudy Vsesoyuznogo Entomologicheskogo Obshchestva, 55, 66-92. [in Russian]

Falkovitsh, M.I. (1979) [Two new species of casebearer moths (Lepidoptera, Coleophoridae) from the Kyzylkum Desert]. In: Medvedev, G.G. (Ed.), [New species of insects from Asiatic part of the USSR]. Trudy Zoologicheskogo Instituta, Akademia Nauk SSSR, 88, pp. 1-128. [in Russian]

Falkovitsh, M.I. (1982) [Three new species of casebearer moths (Lepidoptera, Coleophoridae) from the Transaltai-Gobi]. Nasekomye Mongolii, 8, 335-342. [in Russian]

Glaser, W. (1981) Beitrag zur Kenntnis der Coleophoridae. XIII. Zwei neue Arten aus Südspanien und deren erste Stände (Lepidoptera, Coleophoridae). Zeitschrift der Arbeitsgemeinschaft Österreichischer Entomologen, 33, 42-46.

Hebert, P.D.N., Cywinska, A., Ball, SL. \& deWaard, JR. (2003) Biological identifications through DNA barcodes. Proceedings of the Royal Society of London, Series B (Biological Sciences), 270, 313-321. https://doi.org/10.1098/rspb.2002.2218

Kumar, S., Stecher, G. \& Tamura, K. (2016) MEGA7: Molecular Evolutionary Genetics Analysis. Version 7.0. Molecular Biology and Evolution, 33 (7), 1870-1874. https://doi.org/10.1093/molbev/msw054

Nupponen, K. (2014) Notes on Scythrididae observed during 2012 from southern and western Kazakhstan, with descriptions of six new species. SHILAP Revista de lepidopterologia, 42 (166), 237-255. Available from: http://www.redalyc.org/ articulo.oa? id=45532157004 (Accessed 5 Jun. 2018)

Robinson, G. (1976) The preparation of slides of Lepidoptera genitalia with special reference to the Microlepidoptera. Entomologist's Gazette, 27, 127-132.

Toll, S. (1962) Materialien zur Kenntnis der paläarktischen Arten der Familie Coleophoridae (Lepidoptera). Acta Zoologica Cracoviensia, 7, 577-720, 133 pls. 